\title{
Communication
}

\section{Salix alba Clone Wilting Response to Heat Stress}

\author{
Santa Celma* $*$, Viktorija Vendina and Dagnija Lazdina \\ Latvian State Forest Research Institute SILAVA, Riga Street 111, 2169 Salaspils, Latvia; \\ viktorija.vendina@silava.lv (V.V.); dagnija.lazdina@silava.lv (D.L.) \\ * Correspondence: santa.celma@silava.lv; Tel.: +371-2067-5715
}

\section{check for}

updates

Citation: Celma, S.; Vendina, V.; Lazdina, D. Salix alba Clone Wilting Response to Heat Stress. Agronomy 2021, 11, 1821. https://doi.org/ 10.3390/agronomy11091821

Academic Editor: Arnd Jürgen Kuhn

Received: 13 August 2021

Accepted: 8 September 2021

Published: 10 September 2021

Publisher's Note: MDPI stays neutral with regard to jurisdictional claims in published maps and institutional affiliations.

Copyright: (c) 2021 by the authors. Licensee MDPI, Basel, Switzerland. This article is an open access article distributed under the terms and conditions of the Creative Commons Attribution (CC BY) license (https:// creativecommons.org/licenses/by/ $4.0 /)$.

\begin{abstract}
The selection of most suitable propagation material, as well as the adjustment of existing seedling management practices, are gaining increasing importance to ensure the best outcomes under the long-term setting of climate change. One of the factors to consider is a predicted increase in the frequency and duration of high-temperature periods. Since heat often coincides with drought, these factors are typically assessed together, yet heat stress on its own has received less attention. In this study, we examined the effect of supra-optimal ambient temperature on nine Salix alba clone cuttings wilting under greenhouse conditions and sufficient moisture levels. Most plants are especially vulnerable to extreme conditions in early stages of development. Response to heat varied between clones but, overall, shoots that were taller than $350 \mathrm{~mm}$ were more sensitive to heat stress. The pruning of excess lateral shoots did not show significant improvement in heat tolerance. In total, $96 \%$ of the wilted cuttings proceeded to produce lateral shoots after the cessation of heat stress. It should be studied further if similar patterns are evident in field conditions and if earlier outplanting has a positive effect on cutting vitality.
\end{abstract}

Keywords: high temperature; propagation; nursery; cuttings

\section{Introduction}

It is predicted that, due to climate change, the overall occurrence and frequency of extreme temperature events will increase [1]. Climate change-driven constrains that are expected to arise in the future are especially important to consider when selecting stock for the propagation of perennial plants. In addition to selecting planting material that is site appropriate, long-lived plants must be resilient and withstand both current and future environmental conditions. Under extreme conditions, mature plants exhibit reduced biomass accumulation, growth inhibition, disturbed biochemical processes and cell death. During spring and summer, when shoot growth is at its peak, cold and drought hardiness is expected to be the lowest [2]. Most studies regarding heat stress have focused on food crops, since reproductive parts of the plant are typically most affected by thermal stress, and, thus, the yield depends on plants' ability to withstand these unfavourable conditions [3-11]. At a whole plant level, plants during the juvenile stage are especially sensitive to stressors and their very survival becomes compromised in supra-optimal temperatures [12]. Drought has typically received more attention than heat. Since heat typically accompanies and exacerbates drought stress under field conditions, drought and heat are often assessed together [3]. However, plants respond differently to each of these stressors [8]. For seedlings, it is known that the temperature of the soil is the main concern, and the shading of the potting soil can be helpful in preventing heat-induced damage [13]. Trees propagated by cuttings, such as Salix alba, intended for agroforestry systems, can be expected to act differently to seedlings, and have more resilience potential, as well as greater potential to recover from heat stress. The level of tolerance varies between different cultivars of the same species [14,15]. In several Salicaceae species, drought tolerance has been shown to be sexually dependent as well [16]. Some morphological and physiological features, such as leaf area and thickness of the plant, have shown the potential to serve as 
indicators of heat stress tolerance and thus better suitability for future plantations $[17,18]$. Recognition of the traits that suggest better tolerance to environmental stressors and are easy to identify can support better planting material selection and, thus, better tree plantation establishment results.

In this study, we evaluate the wilting of nine different Salix alba clones under extreme heat conditions.

\section{Materials and Methods}

\subsection{Planting Material}

Nine Salix alba clones were selected for this study. Seven clones originated from Germany, supplied by Northwest German Forest Research Institute, and two clones were of local, Latvian, origin (Table 1). Depending on available material, $20 \mathrm{~cm}$ long cuttings were prepared for propagation.

Table 1. Salix alba clone origin and number of cuttings.

\begin{tabular}{cccc}
\hline Clone & Number of Cuttings & Country of Origin & Name/Place of Origin \\
\hline $0205 \mathrm{~K}$ & 33 & Germany & Pyramidalis \\
0206L & 72 & Germany & Steinach XI \\
$0207 \mathrm{M}$ & 80 & Germany & Rockanje \\
$0208 \mathrm{~N}$ & 72 & Germany & Botanischer Garten München \\
$0211 S$ & 63 & Germany & Isar IX \\
$0214 \mathrm{~W}$ & 72 & Germany & Weide Godesberg \\
$0218 \mathrm{~B}$ & 72 & Germany & Eckartsau \\
LVX1 & 72 & Latvia & Kalsnava \\
LVX2 & 54 & Latvia & Kalsnava \\
\hline
\end{tabular}

\subsection{Study Setting and Measurements}

Salix alba cuttings were planted under greenhouse conditions in 18 cell propagation trays (three by six rows) in the spring of 2021. All seedling trays were top watered, removing the possibility of drought. Developed shoots in the first and third rows of each tray were pruned, leaving two shoots per cutting if more than two shoots had developed. Shoots were left untreated in the middle row. During a period of extreme weather in June (air temperature maximum of $31-33^{\circ} \mathrm{C}$ ), ambient air temperature in the greenhouse was elevated to $35-38^{\circ} \mathrm{C}$ for 3 consecutive days. Salix alba cuttings suffered from heat damage. Shoot vitality was assessed in a binary manner-wilted or healthy. Height of the shoots was measured only in the middle row, shortly prior to the onset of wilting. Six days after the cessation of extreme thermal conditions, it was assessed if wilted shoots had regained their turgor, if lateral shooting had taken place or if the cutting had suffered permanent damage.

\subsection{Data Analysis}

$R$ software version 3.6.2 (2019) was used to analyse and visualise acquired data [19]. For purposes of statistical analysis, wilting occurrence was transformed to percent of shoots wilted per cutting. Generalised linear models with "gaussian" family were used with wilted shoot percentage as response variable and clone, shoot height, shoot count, row of the tray and the tray location on the table as the explanatory variables. The residuals of the model were assessed visually. The best fitting model was selected based on AIC values. Data did not follow normality assumptions; therefore, assessment of differences in wilting among clones was carried out using Dunnett's test with Bonferroni correction.

Cuttings that suffered from non-heat-related dieback were excluded from the analysis, resulting in 585 cuttings and 1286 observations (shoots), of which 201 had their height measured. 


\section{Results}

Wilting occurrence was best explained by shoot height, clone and shoot count per cutting. According to the obtained results, evidence suggests that shoot height had a significantly positive effect on wilting occurrence $(p<0.001)$. Overall, $31 \%$ of shoots were wilted. Most wilting cases were noted at shoot heights of $400-449 \mathrm{~mm} ; 86 \%$ of measured shoots in this class were wilted. Wilting occurrence was also common in height classes 350-399 $\mathrm{mm}$ and $450-476 \mathrm{~mm}, 74$ and 73\%, respectively.

Clones 0206L, 0208N, 0218B and LVX2 had significantly $(p<0.05)$ more wilted shoots than clones 0205K, 0207M, 0214W, 2011S and LVX1. Most wilted clones also exhibited tendency to grow tall shoots, with the exception of the LVX2 clone, which had relatively short yet wilt-prone shoots (Figure 1).

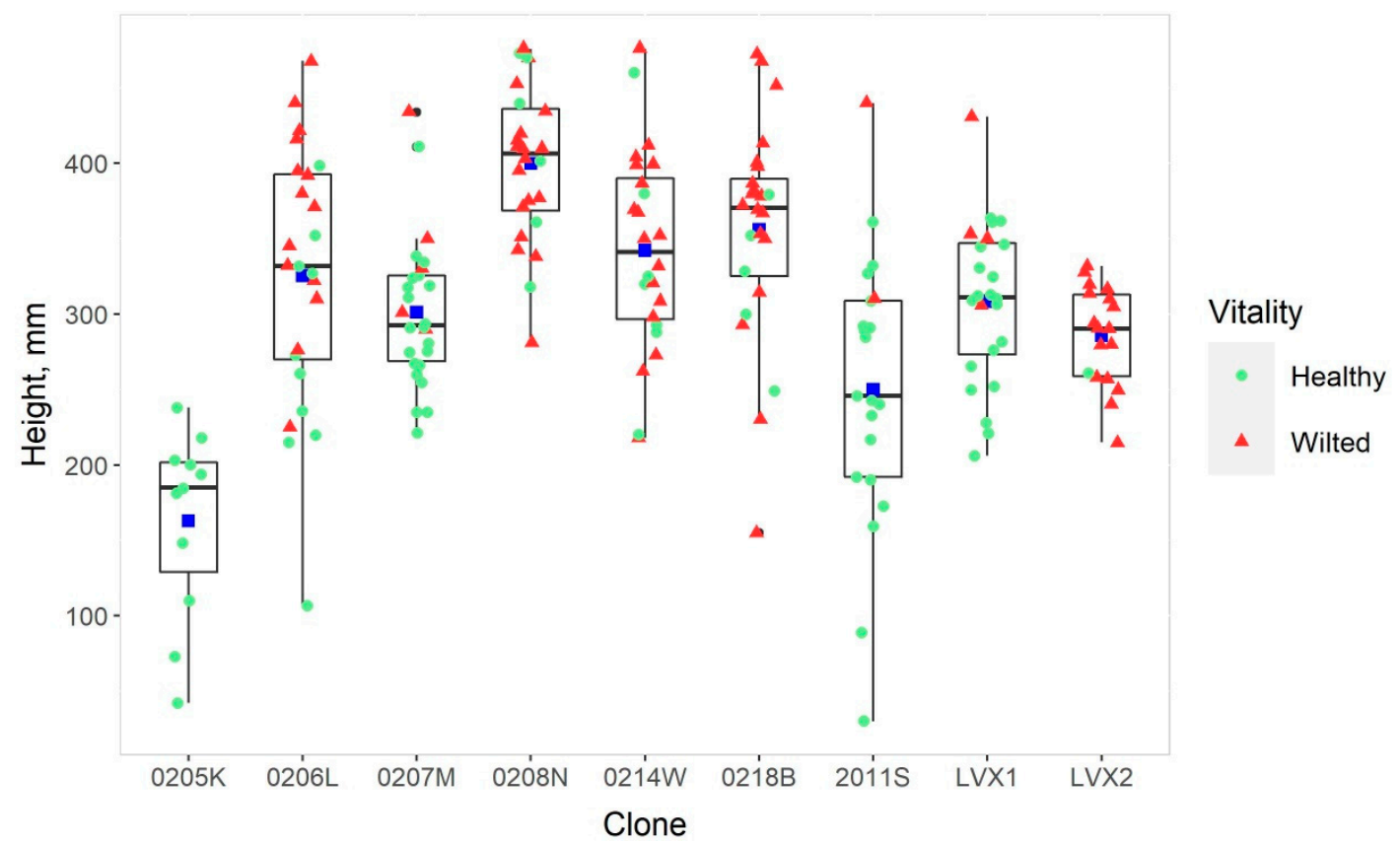

Figure 1. Salix alba leading shoot height and occurrences of wilting shoots (box represent interquartile range; median is shown as the centre horizontal line in the box; whiskers show minimum and maximum observed values plus $1.5^{*}$ interquartile range or minus $1.5^{*}$ interquartile range, respectively; black dots show outliers; mean shoot height is represented by the blue squares).

Shoot count did not have a significant effect on wilting occurrence.

After the cessation of the heat-induced stress period, $11 \%$ of wilted shoots recovered and regained lost turgor. The growing tip of the shoot suffered permanent damage in $89 \%$ of wilted cases. However, lateral shooting took place in $96 \%$ of these cases after the cessation of the stress period. Only $4 \%$ of shoots did not recover and did not exhibit lateral shooting after wilting.

\section{Discussion}

Multiple traits can be useful to estimate plants' ability to tolerate and regenerate after a stress period $[3,20,21]$. Physiological traits are more difficult to assess, compared to morphological traits, yet the importance of morphological traits in determining survival and growth outcomes is often overlooked [22,23] Therefore, the identification of traits that can be easily measured, and are good predictors of drought and heat resistance, can be especially useful in nursery settings, when dealing with a large number of plants. It is known that plants can withstand drought and cold stress better during their dormant stage, but are especially sensitive to these stressors during active phase of shoot growth in spring and summer [2]. A similar pattern is expected to be true for heat stress as well [24]. It is 
also known that heat stress inhibits plant growth and, as a result, plants exposed to heat are shorter $[14,25]$. In this study, evidence was found that plant height affects plants ability to withstand elevated temperatures-short plants are more heat tolerant. Plant height and total leaf area are positively associated with increased evaporation, and, while stomatal conductance is typically reduced under drought conditions, an increase in transpiration is one of the plant mechanisms used to cool the leaves during extreme heat events and, thus, water demand is higher in taller plants [3,26-29]. If the plant cannot support the water and nutritional demand needed for basal metabolic processes and defence mechanisms, wilting occurs [30-32]. In addition, heat tolerance is affected by phytohormones Abscisic Acid (also known as stress hormone) and Ethylene, amongst others, that inhibit plant shoot growth $[14,28]$. Therefore, it is possible that there is variation in phytohormone composition and biosynthesis among the studied clones that determines both the height and heat-tolerance properties.

Our results suggest that protective measures should be taken before shoots reach the more heat-sensitive length of $350 \mathrm{~mm}$ and above. Outplanting of the saplings, mitigation of adverse environmental conditions (by lowering the indoor temperature, providing shading and altering relative humidity) and support of the plants ability to withstand heat stress (by preconditioning the plants or additional application of fertilizers, silicone, phytohormones or other biostimulants) are some of the potential protection measures [5,13,30,32-38]. This study has limitations, since the shoot height was measured only in one of the tray rows in which no shoot removal was carried out. In addition, shoot length is clone dependent. It is expected that critical shoot height will decrease with increasing temperature. This early-stage height-temperature relationship needs to be more extensively studied under controlled conditions.

In this study, it was found that, following the wilting of leading shoots and heat stress cessation, young and short shoots that did not suffer during the event of extreme conditions also proceeded to wither and die. Lateral shooting began to take place afterwards. Even if all shoots had wilted, the cutting itself remained viable and able to produce new shoots. Cuttings in the middle row of the propagation trays, which were not reduced to two or fewer shoots per cutting, had more cases of wilting. However, the shoot count and wilting relationship did not prove to be statistically significant in this study. It was expected that the removal of young, short secondary shoots would contribute to water loss reduction by decreasing total transpiration area and, thus, prevent wilting. Shoot pruning, as well as top pruning, has been shown to improve seedling survival by balancing the shoot-to-root ratio in nurseries and under unfavourable site conditions [39-41]. Whether or not wilting occurrence is affected by height and shoot count in field conditions, where root expansion is not limited in space, should be further studied.

Author Contributions: Conceptualization, D.L.; methodology, D.L., S.C.; formal analysis, S.C.; investigation, S.C., V.V.; data curation, S.C., V.V.; writing—original draft preparation, S.C.; writingreview and editing, D.L., V.V.; visualization, S.C.; supervision, D.L.; project administration, D.L.; funding acquisition, D.L. All authors have read and agreed to the published version of the manuscript.

Funding: Elaboration of innovative White Willow-perennial grass agroforestry systems on marginal mineral soils improved by wood ash and less demanded peat fractions amendments. 1.1.1.1/19/A/112 ERAF.

Acknowledgments: We would like to thank Alwin Janssen the Deputy Director at Northwest German Forest Research Institute for supplying the clone cutting used in this study.

Conflicts of Interest: The authors declare no conflict of interest. The funders had no role in the design of the study, in the collection, analyses, or interpretation of data, in the writing of the manuscript, and in the decision to publish the results. 


\section{References}

1. IPCC. Societal Transformation for Peace in El Salvador; IPCC: Geneva, Switzerland, 2014.

2. Grossnickle, S.C.; Kiiskila, S.B.; Haase, D.L. Seedling ecophysiology: Five questions to explore in the nursery for optimizing subsequent field success. Tree Plant. Notes 2020, 63, 112-127.

3. Lamaoui, M.; Jemo, M.; Datla, R.; Bekkaoui, F. Heat and drought stresses in crops and approaches for their mitigation. Front. Chem. 2018, 6, 26. [CrossRef]

4. Punia, S.M.S.; Yadan, R. Evaluation of mungbean (Vigna radiata L. Wilczek) genotypes for high temperature and drought tolerance. In The Ecoscan, Proceedings of the National Conference on Harmony with Nature in Context of Resource Conservation and Climate Change, Hazaribag, India, 22-24 October 2016; ResearchGate: Berlin, Germany, 2016.

5. Quintero-Calderón, E.H.; Sánchez-Reinoso, A.D.; Chávez-Arias, C.C.; Garces-Varon, G.; Restrepo-Díaz, H. Rice seedlings showed a higher heat tolerance through the foliar application of biostimulants. Not. Bot. Horti Agrobot. Cluj Napoca 2021, $49,12120$. [CrossRef]

6. Mancuso, S. Heat tolerance in olive. Adv. Hortic. Sci. 2002, 16, 125-130.

7. Hussain, H.A.; Men, S.; Hussain, S.; Chen, Y.; Ali, S.; Zhang, S.; Zhang, K.; Li, Y.; Xu, Q.; Liao, C.; et al. Interactive effects of drought and heat stresses on morpho-physiological attributes, yield, nutrient uptake and oxidative status in maize hybrids. Sci. Rep. 2019, 9, 3890. [CrossRef]

8. Zhou, R.; Yu, X.; Ottosen, C.-O.; Rosenqvist, E.; Zhao, L.; Wang, Y.; Yu, W.; Zhao, T.; Wu, Z. Drought stress had a predominant effect over heat stress on three tomato cultivars subjected to combined stress. BMC Plant Biol. 2017, 17, 24. [CrossRef] [PubMed]

9. Dwivedi, S.; Basu, S.; Kumar, S.; Kumar, G.; Prakash, V.; Kumar, S.; Mishra, J.; Bhatt, B.; Malviya, N.; Singh, G.; et al. Heat stress induced impairment of starch mobilisation regulates pollen viability and grain yield in wheat: Study in Eastern Indo-Gangetic Plains. Field Crop. Res. 2017, 206, 106-114. [CrossRef]

10. Chavan, S.G.; Duursma, R.A.; Tausz, M.; Ghannoum, O. Elevated $\mathrm{CO}_{2}$ alleviates the negative impact of heat stress on wheat physiology but not on grain yield. J. Exp. Bot. 2019, 70, 6447-6459. [CrossRef] [PubMed]

11. Sehgal, A.; Sita, K.; Siddique, K.; Kumar, R.; Bhogireddy, S.; Varshney, R.K.; Hanumantha Rao, B.; Nair, R.M.; Prasad, P.V.V.; Nayyar, H. Drought or/and Heat-Stress Effects on Seed Filling in Food Crops: Impacts on Functional Biochemistry, Seed Yields, and Nutritional Quality. Front. Plant Sci. 2018, 871, 1-19. [CrossRef]

12. Hasanuzzaman, M.; Nahar, K.; Alam, M.; Roychowdhury, R.; Fujita, M. Physiological, biochemical, and molecular mechanisms of heat stress tolerance in plants. Int. J. Mol. Sci. 2013, 14, 9643-9684. [CrossRef] [PubMed]

13. Helgerson, O.T. Heat damage in tree seedlings and its prevention. New For. 1989, 3, 333-358. [CrossRef]

14. Li, M.; Jannasch, A.H.; Jiang, Y. Growth and hormone alterations in response to heat stress in perennial ryegrass accessions differing in heat tolerance. J. Plant Growth Regul. 2019, 39, 1022-1029. [CrossRef]

15. Sehgal, A.; Sita, K.; Bhandari, K.; Kumar, S.; Kumar, J.; Prasad, P.V.; Siddique, K.; Nayyar, H. Influence of drought and heat stress, applied independently or in combination during seed development, on qualitative and quantitative aspects of seeds of lentil (Lens culinaris Medikus) genotypes, differing in drought sensitivity. Plant Cell Environ. 2019, 42, 198-211. [CrossRef] [PubMed]

16. Liao, J.; Song, H.; Tang, D.; Zhang, S. Sexually differential tolerance to water deficiency of Salix paraplesia-A female-biased alpine willow. Ecol. Evol. 2019, 9, 8450-8464. [CrossRef]

17. Wright, I.J.; Dong, N.; Maire, V.; Prentice, I.C.; Westoby, M.; Díaz, S.; Gallagher, R.V.; Jacobs, B.F.; Kooyman, R.; Law, E.A.; et al. Global climatic drivers of leaf size. Science 2017, 357, 917-921. [CrossRef]

18. Bhusal, N.; Lee, M.; Lee, H.; Adhikari, A.; Han, A.R.; Kim, H.S. Evaluation of morphological, physiological, and biochemical traits for assessing drought resistance in eleven tree species. Sci. Total. Environ. 2021, 779, 146466. [CrossRef] [PubMed]

19. R.C. Team. R: A Language and Environment for Statistical Computing; R Foundation for Statistical Computing: Vienna, Austria, 2019; Available online: https:/ / www.r-project.org/ (accessed on 28 June 2021).

20. Sreeman, S.M.; Vijayaraghavareddy, P.; Sreevathsa, R.; Rajendrareddy, S.; Arakesh, S.; Bharti, P.; Dharmappa, P.; Soolanayakanahally, R. Introgression of physiological traits for a comprehensive improvement of drought adaptation in crop plants. Front. Chem. 2018, 6, 92. [CrossRef] [PubMed]

21. Olyslaegers, G.; Nijs, I.; Roebben, J.; Kockelbergh, F.; Vanassche, F.; Lakers, M.; Verbelen, J.-P.; Samson, R.; LeMeur, R.; Impens, I. Morphological and physiological indicators of tolerance to atmospheric stress in two sensitive and two tolerant tea clones in South Africa. Exp. Agric. 2002, 38, 397-410. [CrossRef]

22. Andivia, E.; Villar-Salvador, P.; Oliet, J.A.; Puértolas, J.; Dumroese, R.K.; Ivetić, V.; Molina-Venegas, R.; Arellano, E.C.; Li, G.; Ovalle, J.F. Climate and species stress resistance modulate the higher survival of large seedlings in forest restorations worldwide. Ecol. Appl. 2021, 31, e2394. [CrossRef]

23. Zotz, G.; Hietz, P.; Schmidt, G. Small plants, large plants: The importance of plant size for the physiological ecology of vascular epiphytes. J. Exp. Bot. 2001, 52, 2051-2056. [CrossRef]

24. Wisniewski, M.; Sauter, J.; Fuchigami, L.; Stepien, V. Effects of near-lethal heat stress on bud break, heat-shock proteins and ubiquitin in dormant poplar (Populus nigra Charkowiensis x P. nigra incrassata). Tree Physiol. 1997, 17, 453-460. [CrossRef]

25. Khan, Z.; Shahwar, D. Role of heat shock proteins (HSPs) and heat stress tolerance in crop plants. In Sustainable Agriculture in the Era of Climate Change; Roychowdhury, R., Choudhury, S., Hasanuzzaman, M., Srivastava, S., Eds.; Springer Nature Switzerland AG: Cham, Switzerland, 2020; pp. 211-234. 
26. Wang, G.; Zhou, Q.; He, M.; Zhong, X.; Tang, G. Wilting index and root morphological characteristics used as drought-tolerance variety selection at the seedling stage in soybean (Glycine max L.). Plant Growth Regul. 2020, 92, 29-42. [CrossRef]

27. McGregor, I.R.; Helcoski, R.; Kunert, N.; Tepley, A.J.; Gonzalez-Akre, E.B.; Herrmann, V.; Zailaa, J.; Stovall, A.E.L.; Bourg, N.A.; McShea, W.J.; et al. Tree height and leaf drought tolerance traits shape growth responses across droughts in a temperate broadleaf forest. New Phytol. 2021, 231, 601-616. [CrossRef]

28. Ahammed, G.J.; Li, X.; Zhou, J.; Zhou, Y.-H.; Yu, J.-Q. Role of hormones in plant adaptation to heat stress. In Plant Hormones under Challenging Environmental Factors; Ahammed, G.J., Yu, J.-Q., Eds.; Springer: Dordrecht, The Netherlands, 2016.

29. Tzortzakis, N.; Chrysargyris, A.; Aziz, A. Adaptive response of a native Mediterranean grapevine cultivar upon short-term exposure to drought and heat stress in the context of climate change. Agronomy 2020, 10, 249. [CrossRef]

30. Sarwar, M.; Saleem, M.F.; Ullah, N.; Ali, S.; Rizwan, M.; Shahid, M.R.; Alyemeni, M.N.; Alamri, S.; Ahmad, P. Role of mineral nutrition in alleviation of heat stress in cotton plants grown in glasshouse and field conditions. Sci. Rep. 2019, 9, 13022. [CrossRef]

31. Del Castello, F.; Nejamkin, A.; Cassia, R.; Correa-Aragunde, N.; Fernández, B.; Foresi, N.; Lombardo, C.; Ramirez, L.; Lamattina, L. The era of nitric oxide in plant biology: Twenty years tying up loose ends. Nitric Oxide 2019, 85, 17-27. [CrossRef]

32. Waraich, E.; Ahmad, R.; Halim, A.; Aziz, T. Alleviation of temperature stress by nutrient management in crop plants: A review. J. Soil Sci. Plant Nutr. 2012, 12, 221-244. [CrossRef]

33. Saha, G.; Mostofa, M.G.; Rahman, M.; Tran, L.-S.P. Silicon-mediated heat tolerance in higher plants: A mechanistic outlook. Plant Physiol. Biochem. 2021, 166, 341-347. [CrossRef] [PubMed]

34. Mathers, H.M. Summary of temperature stress issues in nursery containers and current methods of protection. HortTechnology 2003, 13, 617-624. [CrossRef]

35. Alam, M.N.; Zhang, L.; Yang, L.; Islam, R.; Liu, Y.; Luo, H.; Yang, P.; Wang, Q.; Chan, Z. Transcriptomic profiling of tall fescue in response to heat stress and improved thermotolerance by melatonin and 24-epibrassinolide. BMC Genom. 2018, 19, 1-14. [CrossRef] [PubMed]

36. Iqbal, M.; Raja, N.I.; Mashwani, Z.-U.-R.; Hussain, M.; Ejaz, M.; Yasmeen, F. Effect of silver nanoparticles on growth of wheat under heat stress. Iran J. Sci. Technol. Trans. A Sci. 2019, 43, 387-395. [CrossRef]

37. Zhang, J.; Shi, Y.; Zhang, X.; Du, H.; Xu, B.; Huang, B. Melatonin suppression of heat-induced leaf senescence involves changes in abscisic acid and cytokinin biosynthesis and signaling pathways in perennial ryegrass (Lolium perenne L.). Environ. Exp. Bot. 2017, 138, 36-45. [CrossRef]

38. Fahad, S.; Bajwa, A.; Nazir, U.; Anjum, S.A.; Farooq, A.; Zohaib, A.; Sadia, S.; Nasim, W.; Adkins, S.; Saud, S.; et al. Crop production under drought and heat stress: Plant responses and management options. Front. Plant Sci. 2017, 8, 1147. [CrossRef]

39. DesRochers, A.; Tremblay, F. The effect of root and shoot pruning on early growth of hybrid poplars. For. Ecol. Manag. 2009, 258, 2062-2067. [CrossRef]

40. Mexal, J.G.; Landis, T.D. Target seedling concepts: Height and diameter. In General Technical Report RM-200, Proceedings of the Target Seedling Symposium: Combined Meeting of the Western Forest Nursery Associations, Roseburg, OR, USA, 13-17 August 1990; Rose, R., Campbell, S.J., Landis, T.D., Eds.; U.S. Department of Agriculture, Forest Service, Rocky Mountain Forest and Range Experiment Station: Roseburg, OR, USA, 1990; pp. 17-35. [CrossRef]

41. South, D.B. Effects of top-pruning on survival of southern pines and hardwoods. In General Technical Report SRS-20, Proceedings of the Ninth Biennial Southern Silvicultural Research Conference, Clemson, SC, USA, 25-27 February 1997; Waldrop, T.A., Ed.; USDA Forest Service Southern Research Station: Ashville, NC, USA, 1998. 